\title{
The Roles of Serum and Carbon Dioxide in Capsule Formation by Bacillus anthracis
}

\author{
BY ELINOR MEYNELL \\ Department of Bacteriology, Wright-Fleming Institute of Microbiology, \\ St Mary's Hospital Medical School, London, W. 2 \\ AND G. G. MEYNELL \\ Guinness-Lister Research Unit, Lister Institute of Preventive Medicine, \\ Chelsea Bridge Road, London, S.W. 1
}

(Received 27 August 1963)

\section{SUMMARY}

Capsule formation by virulent strains of Bacillus anthracis on nutrient agar is known to depend on incubation in air with added $\mathrm{CO}_{2}$ as well as the addition of serum or bicarbonate to the medium. The minimum effective concentration of $\mathrm{CO}_{2}$ varies with the $\mathrm{pH}$ of the medium in a way which shows that capsulation depends on a threshold concentration of bicarbonate in the medium. Serum is more effective than bicarbonate and appears to act by binding an agent which inhibits capsule formation since it is replaceable by activated charcoal. The inhibitor might be a fatty acid since certain acids prevented capsule formation. Capsules are formed on nutrient agar containing added bicarbonate only after the culture has become very dense which suggests that the organisms either inactivate the inhibitor or become resistant to its action as their growth rate falls on approaching the stationary phase.

\section{INTRODUCTION}

Virulent strains of Bacillus anthracis are invariably capsulated in vivo but form capsules in vitro only under special conditions. These include incubation in air with added $\mathrm{CO}_{2}$ (Ivánovics, 1937) and the use of nutrient agar containing either serum (Sterne, 1937) or bicarbonate (see Thorne, 1956). Bicarbonate has displaced serum in recent investigations (see Housewright, 1962) but the naked eye appearance of colonies on serum agar and on bicarbonate agar incubated in the same atmosphere immediately suggests that serum agar gives far better capsulation, and that serum and bicarbonate are therefore not equivalent in capsule formation. This observation, which was repeatedly confirmed in studying the genetic control of capsulation (Meynell, 1963), and also the unusually high concentrations of serum and $\mathrm{CO}_{2}$ said to be required, led to the present work. The results show that serum is replaceable by $0.2 \%(w / v)$ activated charcoal. Both are thought to act by binding an inhibitor which is present in the medium and in their presence 'physiological' concentrations of $\mathrm{CO}_{2}$ suffice for capsule formation. Capsulation on bicarbonate agar is believed to occur only after the inhibitor has become ineffective. Microscopy confirmed this hypothesis for organisms growing on bicarbonate agar became capsulated many hours after those in comparable cultures on serum or charcoal agar. 


\section{METHODS}

Organisms. The principal strain, $2160 \mathrm{~s}$, was a variant of Bacillus anthracis strain 2160, isolated after prolonged incubation of strain 2160 in broth containing $0.025 \%(w / v) \mathrm{CaCl}_{2}$ (Renaux, 1952). It formed shorter chains, and therefore smoother colonies, than typical strains of $B$. anthracis (Nungester, 1929), did not form heat-resistant spores (McCloy, 1958), and was virtually avirulent for mice. However, it behaved like typical strains of this species in forming a capsule only when grown on serum or bicarbonate agar in $\mathrm{CO}_{2}$.

Five typical virulent strains were tested in a few experiments: two capsulated $(\mathrm{C}+)$ strains (1444, Hillsborough) from the authors' stocks, and $\mathrm{C}+$ revertants from three strains (Vollum, A 69, A 77) received as C - mutants from Dr G. Ivánovics (Meynell, 1963).

Media. Only solid media were used. The usual formula was ( $\%, w / v)$ : 'LabLemco', 0.1; Tryptone (Oxoid), 0.2; Peptone (Oxoid), 1; NaCl, 0.7; Davis N.Z. agar, 1.5; $\mathrm{pH} \mathrm{7.4.} \mathrm{In} \mathrm{some} \mathrm{experiments,} \mathrm{Oxoid} \mathrm{Nutrient} \mathrm{Broth} \mathrm{No.} \mathrm{2,} \mathrm{solidified}$ with Oxoid Agar No. 3, $1.5 \%(\mathrm{w} / \mathrm{v})$ was used, either at $\mathrm{pH} 7 \cdot 4$ or $8 \cdot 0$, when it also contained 0.1 M 2-amino-2-hydroxymethylpropane-1,3-diol (tris), or at $\mathrm{pH} 6 \cdot 2$ or $6 \cdot 8$, when inorganic phosphate buffer was added to $0 \cdot 1 \mathrm{~m}$ just before pouring plates. Other supplements were also added to molten agar at this time. Calculated amounts of $\mathrm{NaHCO}_{3}$ were added from a M-solution sterilized by Seitz filtration; the calculations are explained in the legend to Fig. 1. Serum was added to $20 \%(v / v)$. Bovine Serum Albumin Fraction V (batches AN 2070 and GC 1170; Armour Laboratories, Hampden Park, Eastbourne, Sussex) was added to $0.7 \%(\mathrm{w} / \mathrm{v})$ from a $7 \%(\mathrm{w} / \mathrm{v})$ solution in distilled water or in $0.1 \mathrm{~m}$ Sørenson buffer ( $\mathrm{pH} \mathrm{7.6)} \mathrm{sterilized} \mathrm{by} \mathrm{Seitz}$ filtration. Activated charcoal (Norit A or Hopkin and Williams decolorizing charcoal, code 2992 ) was added to $0 \cdot 2 \%(\mathrm{w} / \mathrm{v})$ from a $10 \%(\mathrm{w} / \mathrm{v})$ suspension in distilled water previously sterilized by autoclaving at $121^{\circ}$ for $15 \mathrm{~min}$.

Incubation of media. Plates were inoculated with a loop to give an area of confluent growth and streaks bearing isolated colonies. Cultures incubated in 5-40\% $(\mathrm{v} / \mathrm{v}) \mathrm{CO}_{2}$ were held in anaerobic jars from which the necessary volume of air was evacuated and replaced by pure $\mathrm{CO}_{2}$ : thus, $20 \% \mathrm{CO}_{2}$ implies $20 \%(\mathrm{v} / \mathrm{v}) \mathrm{CO}_{2}+80 \%$ $(\mathrm{v} / \mathrm{v})$ air. In one of the experiments shown in Fig. 1 and Table 1, each jar contained $60 \%$ air, the balance after adding the required amount of $\mathrm{CO}_{2}$ being made up with $\mathbf{N}_{2}$. As this did not affect the results, jars simply contained different proportions of air in the later experiments. Cultures in $2.5 \% \mathrm{CO}_{2}$ were set up in candle jars (Nye \& Lamb, 1936).

Assessing the degree of capsulation. Plates were examined after incubation for 21-24 hr. at $37^{\circ}$. Capsulation is reflected in a mucoid appearance of the growth, and its degree was estimated from the naked-eye appearance of confluent growth and of colonies which were recorded separately as $\mathbf{R}, \mathbf{R S}, \mathbf{S R}, \mathbf{S R}-$ more glistening, $\mathbf{M}+, \mathbf{M}++, \mathbf{M}+++$ or $\mathbf{M}++++$. SR broadly resembles a smooth salmonella colony, and $\mathbf{M}+++$ resembles Klebsiella pneumoniae. The proportion of capsulated organisms was judged from films stained by M'Fadyean's method (1903) with polychrome methylene blue. For degrees of capsulation of $\mathbf{M}+$ or greater, all the organisms appeared capsulated; between $\mathbf{R}$ and $\mathbf{S R}$, the proportion of capsulated organisms increased from $10^{-7}$ to about 0.5 . 


\section{RESULTS}

\section{The role of carbon dioxide}

The concentrations of $\mathrm{CO}_{2}$ customarily used to induce capsulation are exceedingly high (e.g. 20-30\%). This suggested that capsule formation depended not on the atmospheric concentration of $\mathrm{CO}_{2}$ but on the concentration of bicarbonate ion $\left(\mathrm{HCO}_{3}^{-}\right)$in the medium. This hypothesis was tested by growing cultures on agar of various $\mathrm{pH}$ in various concentrations of $\mathrm{CO}_{2}$, since the Henderson-Hasselbalch equation predicts that a given $\left[\mathrm{HCO}_{3}^{-}\right]$is produced by less and less $\mathrm{CO}_{2}$, the higher the $\mathrm{pH}$. The Henderson-Hasselbalch equation can be written

$$
\log \left[\mathrm{HCO}_{3}^{-}\right]=\mathrm{pH}-\mathrm{pK}+\log \left[\mathrm{CO}_{2}\right],
$$

where the $\mathrm{pH}$ is that of the medium; $\mathrm{pK}$ is a constant related to the $\mathrm{pK}_{1}$ of carbonic acid; and $\left[\mathrm{CO}_{2}\right]$ is the molarity of dissolved $\mathrm{CO}_{2}$ and equals $P \alpha\left(\mathrm{CO}_{2}\right) 5 \cdot 87 \times 10^{-7}$. $P$ is the atmospheric pressure, $\alpha$ is the solubility of $\mathrm{CO}_{2}$, and $\left(\mathrm{CO}_{2}\right)$ is the $\%(\mathrm{v} / \mathrm{v})$

Table 1. Degree of capsulation of Bacillus anthracis strain $2160 \mathrm{~s}$ on various media of different $\mathrm{pH}$ incubated in various concentrations of carbon dioxide

\begin{tabular}{|c|c|c|c|c|c|c|c|c|c|c|c|}
\hline \multirow[b]{2}{*}{$\begin{array}{c}\text { Medium } \\
\text { Nutrient agar }\end{array}$} & \multirow[b]{2}{*}{$\mathrm{pH}$} & \multicolumn{2}{|l|}{2.0} & \multicolumn{2}{|l|}{0} & \multicolumn{2}{|l|}{ 10 } & \multicolumn{2}{|l|}{20} & \multicolumn{2}{|l|}{40} \\
\hline & & conf. & col. & conf. & col. & conf. & col. & conf. & col. & conf. & col. \\
\hline$+\mathrm{NaHOO}_{8}$ & $\begin{array}{l}6 \cdot 2 \\
6 \cdot 8 \\
7 \cdot 4 \\
8 \cdot 0\end{array}$ & $\begin{array}{l}\text { RS } \\
\text { RS } \\
\text { RS } \\
\text { RS }\end{array}$ & $\begin{array}{l}R \\
R \\
R \\
\text { SR }\end{array}$ & $\begin{array}{l}\mathrm{RS} \\
\mathrm{RS} \\
\mathrm{SR} \\
\mathrm{M}+\end{array}$ & $\begin{array}{l}\mathrm{R} \\
\mathrm{R} \\
\mathrm{RS} \\
\mathrm{SR}\end{array}$ & $\begin{array}{l}\mathrm{RS} \\
\mathrm{SR} \\
\mathrm{M}+ \\
\mathrm{M}++\end{array}$ & $\begin{array}{l}\mathrm{R} \\
\mathrm{RS} \\
\mathrm{M}+ \\
\mathrm{M}++\end{array}$ & $\begin{array}{l}\text { RS } \\
\text { SR } \\
\text { M }++ \\
\text { M++ }\end{array}$ & $\begin{array}{l}\mathrm{R} \\
\mathrm{SR} \\
\mathrm{M}++ \\
\mathrm{M}++\end{array}$ & $\begin{array}{l}\mathbf{R S} \\
\mathbf{M}++ \\
\mathbf{M}++ \\
\mathbf{M}++\end{array}$ & $\begin{array}{l}\mathbf{R} \\
\mathbf{M}+ \\
\mathbf{M}++ \\
\mathbf{N G}\end{array}$ \\
\hline $\begin{array}{l}+\mathrm{NaHCO}_{3}+\text { albumin } \\
\text { or charcoal }\end{array}$ & $\begin{array}{l}6 \cdot 2 \\
6 \cdot 8 \\
7 \cdot 4 \\
8 \cdot 0\end{array}$ & $\begin{array}{l}\text { RS } \\
\text { SR } \\
\text { SR } \\
\text { SR }\end{array}$ & $\begin{array}{l}\mathbf{R} \\
\mathbf{M}++ \\
\mathbf{M}++ \\
\mathbf{M}++\end{array}$ & $\begin{array}{l}\mathrm{RS} \\
\mathbf{M}++ \\
\mathbf{M}++ \\
\mathbf{M}++\end{array}$ & $\begin{array}{l}\mathbf{R} \\
\mathbf{M}+++ \\
\mathbf{M}++ \\
\mathbf{M}+++\end{array}$ & $\begin{array}{l}\mathrm{SR} \\
\mathrm{M}+++ \\
\mathrm{M}+++ \\
\mathrm{M}+++\end{array}$ & $\begin{array}{l}\text { SR } \\
\mathrm{M}+++ \\
\mathrm{M}+++ \\
\mathrm{M}+++\end{array}$ & $\begin{array}{l}\mathbf{M}+ \\
\mathbf{M}+++ \\
\mathbf{M}+++ \\
\mathbf{M}+++\end{array}$ & $\begin{array}{l}\mathbf{M}+ \\
\mathbf{M}+++ \\
\mathbf{M}+++ \\
\mathbf{M}+++\end{array}$ & $\begin{array}{l}\mathbf{M}++ \\
\mathbf{M}+++ \\
\mathbf{M}+++ \\
\mathbf{M}+++\end{array}$ & $\begin{array}{l}\mathbf{M}++ \\
\mathbf{M}+++ \\
\mathbf{M}+++ \\
\mathbf{M}+++\end{array}$ \\
\hline No supplement & $\begin{array}{l}6 \cdot 2 \\
6 \cdot 8 \\
7 \cdot 4 \\
8 \cdot 0\end{array}$ & $\begin{array}{l}\text { RS } \\
\text { RS } \\
\text { SR } \\
\text { RS }\end{array}$ & $\begin{array}{l}\mathbf{R} \\
\mathbf{R} \\
\mathbf{R} \\
\mathbf{R S}\end{array}$ & $\begin{array}{l}\text { RS } \\
\text { RS } \\
\text { SR } \\
\text { RS }\end{array}$ & $\begin{array}{l}\mathbf{R} \\
\mathbf{R} \\
\mathbf{R S} \\
\mathbf{R S}\end{array}$ & $\begin{array}{l}\text { RS } \\
\text { SR } \\
\text { SR } \\
M+\end{array}$ & $\begin{array}{l}\mathbf{R} \\
\mathbf{S R} \\
\mathbf{S R} \\
\mathbf{M}+\end{array}$ & $\begin{array}{l}\text { RS } \\
\text { SR } \\
\text { SR } \\
M+\end{array}$ & $\begin{array}{l}\mathbf{R} \\
\mathrm{SR} \\
\mathrm{SR} \\
\mathbf{M}+\end{array}$ & $\begin{array}{l}\text { SR } \\
\text { SR } \\
\text { SR } \\
\mathbf{M}+\end{array}$ & $\begin{array}{l}\text { R } \\
\text { SR } \\
\text { SR } \\
\mathbf{M}+\end{array}$ \\
\hline + Charcoal & $\begin{array}{l}6 \cdot 2 \\
6 \cdot 8 \\
7 \cdot 4 \\
8 \cdot 0\end{array}$ & $\begin{array}{l}\text { RS } \\
\text { RS } \\
\text { RS } \\
\text { SR }\end{array}$ & $\begin{array}{l}\mathrm{R} \\
\mathrm{RS} \\
\mathrm{M}+ \\
\mathrm{M}++\end{array}$ & $\begin{array}{l}\mathbf{R S} \\
\mathbf{M}+ \\
\mathbf{M}+ \\
\mathbf{M}++\end{array}$ & $\begin{array}{l}\mathbf{R} \\
\mathbf{M}++ \\
\mathbf{M}++ \\
\mathbf{M}++\end{array}$ & $\begin{array}{l}\mathrm{RS} \\
\mathrm{M}++ \\
\mathrm{M}+ \\
\mathbf{M}++\end{array}$ & $\begin{array}{l}\mathbf{R S} \\
\mathbf{M}++ \\
\mathbf{M}++ \\
\mathbf{M}++\end{array}$ & $\begin{array}{l}\mathbf{M}+ \\
\mathbf{M}+++ \\
\mathbf{M}++ \\
\mathbf{M}+++\end{array}$ & $\begin{array}{l}\mathbf{M}+ \\
\mathbf{M}+++ \\
M++ \\
M+++\end{array}$ & $\begin{array}{l}\mathbf{M}++ \\
\mathbf{M}+++ \\
\mathbf{M}++ \\
\mathbf{M}+++\end{array}$ & $\begin{array}{l}\mathbf{M}++ \\
\mathbf{M}+++ \\
\mathbf{M}+++ \\
\mathbf{N G}\end{array}$ \\
\hline
\end{tabular}

of atmospheric $\mathrm{CO}_{2}$ (see Umbreit, Burris \& Stauffer, 1957, chapter 2). It follows that $\log \left[\mathrm{HCO}_{3}^{-}\right]$plotted against $\log \left[\mathrm{CO}_{2}\right]$ for a given $\mathrm{pH}$ gives a straight line and that the plots for different $\mathrm{pH}$ form a series of parallel straight lines (Fig. 1). Hence, as stated above, a given $\left[\mathrm{HCO}_{3}^{-}\right]$is produced by a variety of combinations of $\left[\mathrm{CO}_{2}\right]$ and $\mathrm{pH}$.

Cultures on nutrient agar plates, buffered at $\mathrm{pH} 6 \cdot 2,6 \cdot 8,7 \cdot 4$, or $8 \cdot 0$, and supplemented with appropriate concentrations of $\mathrm{NaHCO}_{3}$, were incubated overnight in different $\mathrm{CO}_{2}$ concentrations and examined for capsulation. Figure $1 a$ and Table 1 show that capsule production depended entirely on the concentration of $\mathrm{HCO}_{3}$ - in the medium since it occurred with any combination of $\mathrm{pH}$ and $\mathrm{CO}_{2}$, provided that at least $0.056 \mathrm{M}-\mathrm{HCO}_{3}-$ was present in the medium. 


\section{The role of serum}

The early experiments on capsulation used nutrient agar containing a high concentration of horse serum (Sterne, 1937) and concentrations of $20 \%(\mathrm{v} / \mathrm{v})$ or more have been used ever since. Our initial supposition was that serum acted as a buffer, increasing the concentration of $\mathrm{HCO}_{3}$ - formed in the medium at a given $\mathrm{CO}_{2}$ concentration in the same way as an increase in $\mathrm{pH}$ or addition of $\mathrm{NaHCO}_{3}$. Two observations, however, were against this explanation. First, the buffering power of the broth used for these experiments was hardly changed by adding $20 \%(\mathrm{v} / \mathrm{v})$ horse serum and remained less than that of tryptic digest broth which gave less capsulation (Fig. 2). Secondly, overnight cultures on serum agar were far more mucoid than those on bicarbonate agar, the difference being most striking

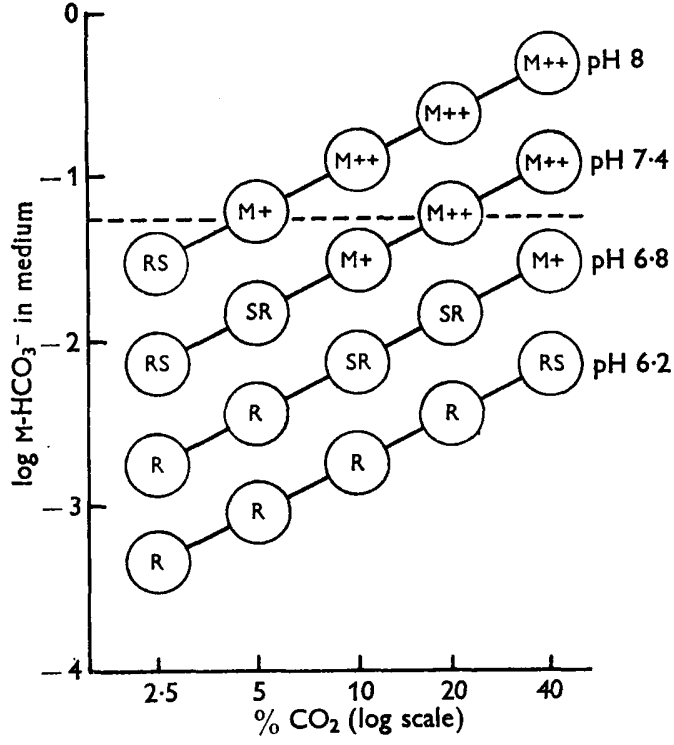

(a)

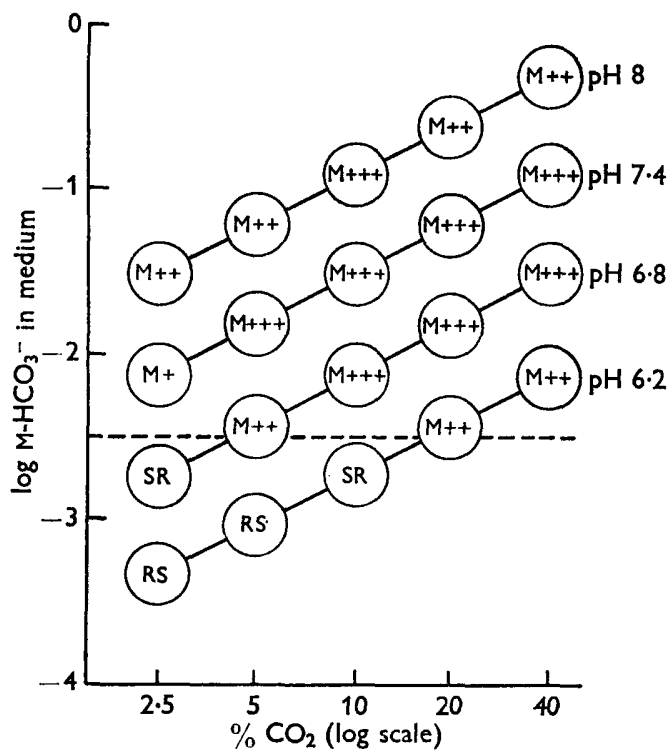

(b)

Fig. 1. Relation of bicarbonate ion $\left(\mathrm{HCO}_{3}{ }^{-}\right)$concentration to atmospheric content of $\mathrm{CO}_{2}$ at various values of $\mathrm{pH}$. The lines show the relations predicted for $\mathrm{pH} 6 \cdot 2,6 \cdot 8,7 \cdot 4$, and $8 \cdot 0$ by the Henderson-Hasselbalch equation, with $\mathrm{pK}=6.32 ; \mathrm{P}=760 \mathrm{~mm}$. $\mathrm{Hg}$; and $\alpha=0.56 \mathrm{ml} . / \mathrm{ml}$. at $37^{\circ}$. The amounts of $\mathrm{NaHCO}_{3}$ added to plates were also calculated from these values. The letters enclosed by circles indicate the degree of capsulation produced by strain $2160 \mathrm{~s}$ after overnight incubation at $37^{\circ}$. Nutrient agar at $\mathrm{pH} 6.2$ and 6.8 was buffered with $0 \cdot 1 \mathrm{M}$-inorganic phosphate and at $\mathrm{pH} 7 \cdot 4$ and $8 \cdot 0$ with $0 \cdot 1 \mathrm{M}$ tris. In addition, the calculated amount of $\mathrm{NaHCO}_{3}$ was added to buffer $\mathrm{H}_{2} \mathrm{CO}_{3}$ formed in the medium by solution of $\mathrm{CO}_{2}$, leaving the phosphate or tris to maintain the initial pH during growth of the culture. All the media had certain points in common. Capsulation never occurred at any $\mathrm{pH}$ after incubation in air $\left(0.03 \% \mathrm{CO}_{2}\right)$. Colonial diameters were respectively half and a quarter those of the controls when the $\mathrm{HCO}_{3}$ - concentration was in the ranges $0.01-0.07 \mathrm{M}$ and $0.07-0.1 \mathrm{M}$. Only pin-point colonies were seen with $\mathrm{HCO}_{3}{ }^{-}$concentrations exceeding $0 \cdot 1 \mathrm{M}$, and thickly inoculated areas of the plates showed only a watery smear of growth. (a) Plates with added $\mathrm{NaHCO}_{3}$ only. (b) Plates with $\mathrm{NaHCO}_{3}$ and either $0.7 \%(\mathrm{w} / \mathrm{v})$ albumin or $0.2 \%(\mathrm{w} / \mathrm{v})$ charcoal. The dashed lines show the threshold $\mathrm{HCO}_{3}$ - concentration above which mucoid growth occurred. The threshold for bicarbonate agar is $0.056 \mathrm{~m}$, about 18 times greater than for albumin or charcoal agar, where it is $0.0032 \mathrm{M}$. 
with isolated colonies. In addition, there were quite marked differences in the capsule-promoting activity of different batches of serum; some were almost inactive. The sera of different animal species are known to differ markedly in this respect (Dr H. Smith, personal communication) and, in limited tests with single batches of human, sheep, and calf sera, we found that all were much more active than horse serum. Human serum showed the most activity, followed by calf and sheep serum.

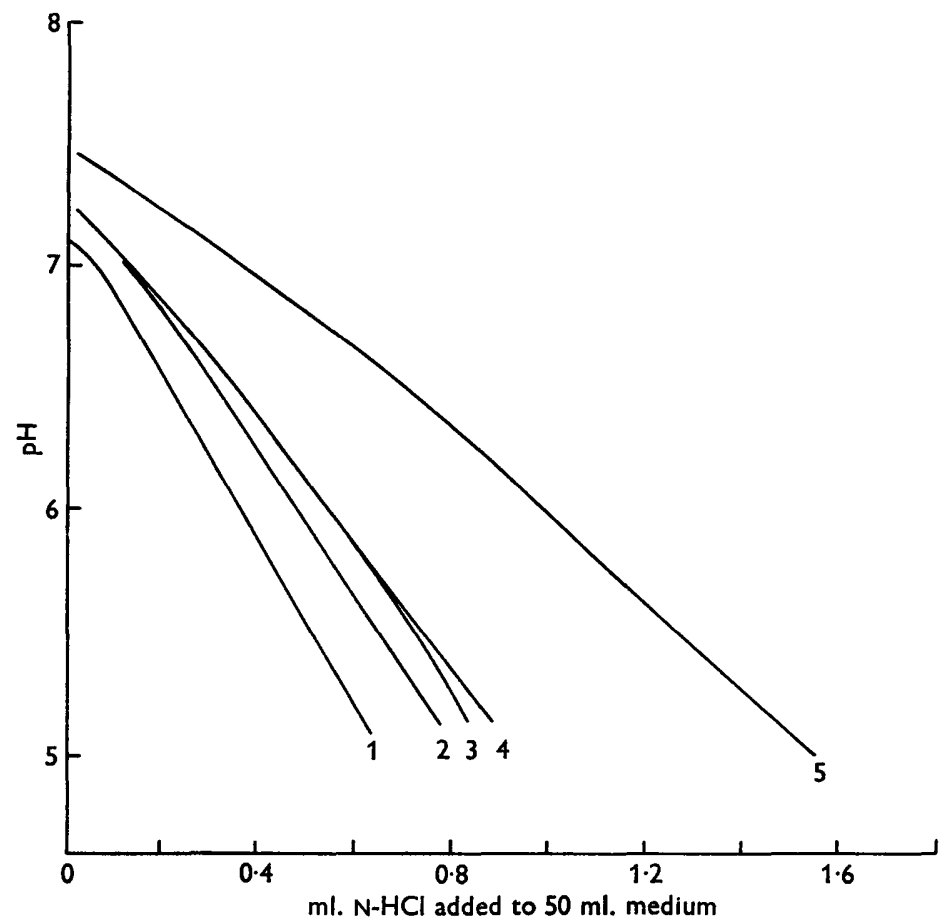

Fig. 2. Titration curves of different liquid media. The buffering capacity is inversely proportional to the slope of the titration curve. Key to curves: 1, Lemco broth+ $0.7 \%(w / v)$ albumin dissolved in water; 2 , Lemco broth $+20 \%(v / v)$ horse serum; 3, Lemco broth $+0.7 \%(\mathrm{w} / \mathrm{v})$ albumin dissolved in $0.1 \mathrm{M}$-phosphate buffer; 4 , Lemco broth alone; 5 , Tryptic digest broth.

Massive capsulation resulted when horse serum was replaced by Bovine Serum Albumin Fraction $V$ added to the medium in a concentration equal to that of the albumin provided by whole serum. The same order of capsulation was obtained whether the stock albumin solution was made in distilled water or in $0 \cdot 1 \mathrm{M}$-phosphate buffer (pH 7.6). Capsulation occurred on albumin agar when the bacteria were separated from the medium by cellophan (a.p.d., $3 \mathrm{~m} \mu$ ) or by gradocol membranes (a.p.d., $5 \mathrm{~m} \mu$ ), regardless of whether they were inoculated on a membrane placed on the surface of the agar or across unsupplemented agar separated from albumin agar by a strip of cellophan. In the second case, the growth on nutrient agar next to the cellophan was more capsulated than that farther away.

These results suggested that albumin (and presumably serum) acted either by absorbing a low molecular weight inhibitor of capsulation from the medium or by 
providing a dialysable factor which promoted capsule formation. Binding of an inhibitor was strongly supported by finding that activated charcoal $(0 \cdot 2 \%, \mathrm{w} / \mathrm{v})$ was just as efficient as albumin in promoting capsulation. On either medium incubated in 10-20\% $\mathrm{CO}_{2}$, isolated colonies were so mucoid that they coalesced and the confluent growth sometimes poured into the lid of the plate. It seemed very improbable that charcoal contributed a stimulating factor, since either of two brands were active (Norit $\mathbf{A}$ or Hopkin and Williams), whether used as supplied or after successively refluxing with equal parts of chloroform and methanol for $6 \mathrm{hr}$, heating in $6 \mathrm{~N}-\mathrm{HCl}$ for $30 \mathrm{~min}$. at $121^{\circ}$ followed by repeated washing with boiling distilled water, and heating to redness in nitrogen for $1 \mathrm{hr}$.

The effects of albumin and charcoal were examined in more detail by retesting the influence of $\mathrm{CO}_{2}$ concentration and pH. Fig. $1 b$ shows that, while the general relation found for bicarbonate agar also held for these media, the threshold $\mathrm{HCO}_{3}{ }^{-}$ concentration required for capsulation was lowered about 18-fold. No capsulation occurred on either medium when incubated in air. The lowering of the threshold explains why capsulation was obtained on unbuffered medium containing albumin or charcoal despite some fall in $\mathrm{pH}$ on incubation in $\mathrm{CO}_{2}$ (Table 1). It appears that capsulation can occur either with a low $\mathrm{HCO}_{3}-$ threshold even when the $\mathrm{pH}$ falls (albumin or charcoal agar) or with a high threshold when the fall in $\mathrm{pH}$ is prevented (bicarbonate agar). As expected, the maximum amount of capsulation was produced when the $\mathrm{pH}$ was maintained and the $\mathrm{HCO}_{3}-$ threshold was lowered (albumin or charcoal agar + bicarbonate buffer).

These observations also explain why capsulation does not occur on conventional nutrient agar at $\mathrm{pH} 7 \cdot 4$. On exposure to $\mathrm{CO}_{2}$, sufficient carbonic acid forms in the medium to lower its $\mathrm{pH}$ and, consequently, to raise still further the concentration of $\mathrm{CO}_{2}$ needed in the atmosphere to produce the threshold concentration of $\mathrm{HCO}_{3}{ }^{-}$. However, capsulation occurs, as expected, when the agar is made exceptionally alkaline before incubation in $\mathrm{CO}_{2}$, e.g. by raising the $\mathrm{pH}$ to 8.5 with an alkali like $\mathrm{NaOH}$ (Thorne, Gomez \& Housewright, 1952) or by adding bicarbonate (Thorne, 1956).

Other absorbents were also tested ('Table 2). Coarse granular charcoal (British Drug Houses Ltd., for gas absorption; Holt, 1962) definitely promoted capsulation, although less efficiently than the finely particulate Norit and Hopkin and Williams charcoals, probably because the coarse granules sank to the bottom of the plate. Florisil was weakly active; its particles also tended to sink and its relative inefficiency might also have been due to poor dispersion. Alumina, silicic acid and cholesterol (Lwoff, 1947) produced a slight increase in the proportion of capsulated bacteria in the confluent growth as compared with the controls, but too inconstantly to prove their capsule-promoting activity. The anion-exchangers, DEAE and Amberlite CG-400, had definite activity, while the cation-exchangers, CEC and Amberlite CG-120, appeared to have none. Starch promoted capsulation, though not to the same extent as albumin or charcoal, and isolated colonies were usually more mucoid than the confluent growth and contained a higher proportion of capsulated organisms. The effect of starch might have been lessened owing to its hydrolysis by the amylase produced by the bacteria (Smith, Gordon \& Clark, 1952; Knight \& Proom, 1950). Alternatively, glucose formed by hydrolysis may have depressed capsule formation (see Discussion). 
Table 2. Action of absorbents in promoting capsulation of Bacillus anthracis strain $2160 \mathrm{~s}$

Each absorbent was incorporated in nutrient agar pH $7 \cdot 4$ which was incubated in $20 \% \mathrm{CO}_{2}$.

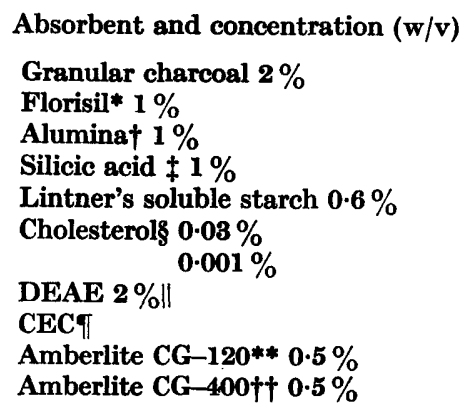

$\begin{array}{cl}\begin{array}{c}\text { Proportion of } \\ \text { capsulated } \\ \text { organisms in } \\ \text { isolated } \\ \text { colonies }\end{array} & \\ 0 \cdot 05 & \text { Capsulogenic effect } \\ 0 \cdot 01-0 \cdot 05 & \text { Slight } \\ 10^{-8} & \text { Slight } \\ 10^{-8} & \text { None } \\ 0 \cdot 1-\mathbf{M}++ & \text { None } \\ 10^{-6} & \text { Inconstant } \\ 10^{-6} & \text { None } \\ 0 \cdot 8 & \text { None } \\ 10^{-5} & \text { Probable } \\ 10^{-8} & \text { None } \\ \mathbf{M}++ & \text { None } \\ & \text { Probable }\end{array}$

* 60-100 mesh magnesium silicate (L. Light and Co.).

† Grade 1 (M. Woelm).

\$ 100 mesh (Mallinckdrodt).

\$ Added from a $0.1 \%, w / v$, emulsion in water.

II $N, N$-Diethylaminoethyl cellulose (Eastman Organic Chemicals).

T Cellex-CM. Carboxyl methyl cellulose (Bio-Rad laboratories).

** Cation-exchange resin (British Drug Houses Ltd).

t† Anion-exchange resin (British Drug Houses Ltd).

\section{Relation of capsule formation on bicarbonate agar to bacterial concentration}

If, in fact, albumin and charcoal removed an inhibitor of capsule formation from the medium, it remained to account for capsule formation on bicarbonate agar. Two possibilities were that the effect of the inhibitor was overcome by $\mathrm{HCO}_{3}^{-}$ concentrations permitting capsulation so that bicarbonate agar effectively resembled albumin or serum agar; or that the inhibitor ceased to affect the bacteria after their concentration had become fairly high. These alternatives could therefore be distinguished by seeing whether organisms growing on bicarbonate agar in appropriate concentrations of $\mathrm{CO}_{2}$ were capsulated throughout growth like other species (Meynell, 1961), which is consistent with the first explanation; or whether capsules only appeared late in the growth of the culture after the inhibitor had become inactive. A corollary of the second explanation is that capsulation should appear far earlier in cultures on albumin or charcoal agar in which the inhibitor is assumed to be inactive.

Plates of bicarbonate, albumin, or charcoal agar at $\mathrm{pH} \mathrm{7 \cdot 4}$ were flooded with non-capsulated bacteria from an overnight culture grown in air, allowed to dry, and then incubated in $\mathrm{CO}_{2}$ at $37^{\circ}$. Impressions were made every hour from blocks cut from each of three plates of each medium, stained with M'Fadyean's polychrome methylene blue, and examined. Initially, isolated organisms and short chains were seen. In later specimens, when the growth was too dense for impressions, either smears were made or a small amount of the growth was rubbed up in water. 
Initially, on all three media, no sign of capsule was present and the bacteria were short, broad and vacuolated, the appearance associated with stationary phase cultures of this strain. After 2-3 hr. fairly long chains of thinner organisms formed, often lying side by side; and after 5-7 hr. a progressively more dense mass of tangled organisms was seen. On bicarbonate agar, about $1 / 10^{6}$ fully capsulated organisms or chains were seen from the 4 th to the 9 th hour but uniform capsulation never appeared before $11 \mathrm{hr}$., that is, several hours after dense confluent growth had formed. On albumin agar or charcoal agar, most of the bacteria showed capsules after $\mathbf{3} \mathrm{hr}$. incubation, first seen as a red flush around most of the organisms with sometimes a red granularity. All were definitely capsulated by $4-5 \mathrm{hr}$. The degree of capsulation after $3 \mathrm{hr}$. was equivalent to that seen on bicarbonate agar after about $11 \mathrm{hr}$. Moreover, after $10 \mathrm{hr}$., the growth on albumin or charcoal agar was glistening and easily suspended in saline, whereas the growth on bicarbonate agar had a dull rough surface and formed a more granular suspension.

The results were the same whether plates with $0.025 \mathrm{M}-\mathrm{NaHCO}_{3}$ were compared with charcoal and albumin plates without $\mathrm{NaHCO}_{3}$ incubated in $30 \% \mathrm{CO}_{2}$ or whether plates containing $0.03 \mathrm{M}$ added $\mathrm{NaHCO}_{3}$ incubated in $10 \% \mathrm{CO}_{2}$ were compared with charcoal or albumin plates containing $0.015 \mathrm{M}-\mathrm{NaHCO}_{3}$ incubated in $5 \% \mathrm{CO}_{2}$, conditions which gave approximately equal capsulation after overnight incubation.

These results therefore support the view that the inhibitor removed from nutrient agar by charcoal or albumin becomes ineffective and ceases to prevent capsulation on bicarbonate agar once the bacteria have become sufficiently dense. Before that, the bacteria grew without capsules on bicarbonate agar. This conclusion was strengthened by the observation that on bicarbonate agar isolated colonies were always less mucoid than confluent growth, and that colonies which happened to be very near confluent growth were often markedly more mucoid than those on other parts of the plate. This was not generally seen on albumin or charcoal agar. Although these were the usual findings, the colonial and confluent growth could differ in three other ways.

(a) Where isolated colonies were more mucoid and contained a higher proportion of capsulated bacteria than did confluent growth. This was sometimes observed in the presence of albumin or charcoal with borderline concentrations of $\mathrm{HCO}_{3}^{-}$ $($ c. 0.004 M), and also on certain other media, such as acid-hydrolysed casein + yeast extract, which gave poor growth. It seems likely that here it was not the inhibitor that limited capsule formation, but either $\mathrm{HCO}_{3}^{-}$or a nutrient supplied by the medium.

(b) Where a mucoid rim formed round less mucoid, or non-mucoid, confluent growth. This was always seen when albumin or charcoal agar plates were inoculated by flooding and the growth formed after incubation in $\mathrm{CO}_{2}$ was interrupted by bare areas which either had been left uninoculated or were produced by antibiotics (Table 3). Here again, some factor in the medium other than the inhibitor was probably limiting capsulation. A mucoid rim was also seen with some plates inoculated by loop: when they contained charcoal or albumin, where the isolated colonies were generally mucoid; and when they contained only bicarbonate, where the isolated colonies were rough and capsulation was evidently limited not only by a nutrient in the medium but also depended on there being a sufficient concentration of bacteria. 
(c) Where mucoid growth only occurred in a few colonies situated very close to confluent growth. This was seen very occasionally on plates without absorbent with calculated concentrations of $\mathrm{HCO}_{3}{ }^{-}$of $1 \cdot 8-3 \cdot 2 \times 10^{-3} \mathrm{M}$. It probably indicated a more extreme shortage of the necessary nutrient in the medium and removal of the inhibitor by confluent growth.

Table 3. Effect of various agents on capsule formation by Bacillus anthracis strain $2160 \mathrm{~S}$

Nutrient agar plates at $\mathrm{pH} 7 \cdot 4$ containing Norit $A$ charcoal were inoculated by flooding, and the test agents were placed in wells cut with a cork borer. The plates were incubated in $20 \% \mathrm{CO}_{2}$.

Agent and concentration (w/v) in wells*

\begin{tabular}{|c|c|}
\hline $\begin{array}{c}\% \text { charcoal } \\
\text { in agar } \\
(w / v)\end{array}$ & $\begin{array}{l}\text { Width of } \\
\text { growth } \\
\text { inhibition } \\
\text { zone } \\
\text { (mm.) }\end{array}$ \\
\hline
\end{tabular}

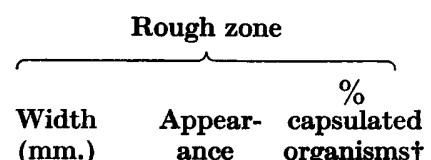

Agar extract

$0 \cdot 2$

Oleic acid $5 \%$

0.04

Palmitic acid $10 \%$

0.2

$0 \cdot 08$

0.2

0.08

Linolenic acid $12 \%$

0.2

Linoleic acid $12 \%$

$0 \cdot 2$

$0 \cdot 2$
0.08

Stearic acid $10 \%$

$0 \cdot 2$

$0 \cdot 08$

Sodium deoxycholate $10 \%$

$0 \cdot 2$

0.04

Proflavine $1 \%$

Streptomycin 0.1\%

$0 \cdot 2$

0.04

$0 \cdot 2$

0.04

0
0
3
3
0
0
10
10
6
6
0
0
7
7
7
7
15
15

$0 \cdot 2-0 \cdot 04$

5-20

o

Rim

Erythromycin 0.1\%

Kanamycin 0.1\%

Furadantin 0.1\%

* Each well contained 0.06-0.08 $\mathrm{ml}$. The $\mathrm{pH}$ of the solutions was $c .7 \cdot 2$.

$\dagger$ Percentage of capsulated organisms in the rough zone. $a,<5 \% ; b, 10-50 \%$. Controls invariably had $100 \%$. - = not tested.

¥ Agar extract: $15 \mathrm{~g}$. Davis agar was refluxed with equal parts of chloroform and methanol for $6 \mathrm{hr}$. The extract was evaporated to dryness and the lipoidal residue warmed in dilute $\mathrm{NaOH}$. Part of the residue did not dissolve. The turbid suspension was neutralized and made up to $10 \mathrm{ml}$.

$\S$ Rim : raised mucoid rim formed round the inhibition zone.

\section{The nature of the inhibitor}

The need for albumin or charcoal immediately suggested that the inhibitor might be a fatty acid present in the medium (see Pollock, 1949; Nieman, 1954). Against this is the fact that although these acids frequently inhibit bacterial growth, they have never been reported to inhibit specifically a function, like 
capsulation, unconnected with growth. Various fatty acids and other agents were tested by placing them in wells cut in a plate of inoculated charcoal agar that was then incubated in $\mathrm{CO}_{2}$ (Table 3). Lipoidal material isolated from agar by refluxing with chloroform + methanol inhibited capsule formation without detectably inhibiting growth, as did the fatty acids, palmitic and stearic. It does not follow, of course, that either acid is the postulated inhibitor, a conclusion which would require analysis of the medium before and during growth of the culture. Moreover, the same effect was produced by sodium deoxycholate which was not likely to be present in the media. Other fatty acids, e.g. linolenic acid, inhibited growth as well as capsule formation; this appears to be a specific effect, since all the chemotherapeutic agents tested inhibited growth alone. A mucoid rim sometimes surrounded the inhibition zone, as already mentioned in the preceding section.

\section{Tests with typical virulent strains}

Five typical strains of Bacillus anthracis (1444, Hillsborough, Vollum, A69, A77) were grown on the different media to show that strain $2160 \mathrm{~s}$ was not exceptional. The results were much the same with all six strains, though there may have been some quantitative differences in their requirements. All five typical strains were heavily capsulated $(\mathrm{M}++++)$ on media containing $0.03 \mathrm{M}-\mathrm{NaHCO}_{3}$ and either charcoal $(0.2 \%, \mathrm{w} / \mathrm{v})$ or albumin $(0.7 \%, \mathrm{w} / \mathrm{v})$ incubated in $10 \% \mathrm{CO}_{2}$. They also produced capsules on bicarbonate agar and on albumin or charcoal agar, but their growth, particularly that of strain A77, was not nearly so mucoid as when absorbent and bicarbonate were both present.

\section{DISCUSSION}

The results shown in Fig. 1 largely account for the high concentrations of $\mathrm{CO}_{2}$ and of serum customarily used to induce capsule formation in vitro. The $\mathrm{CO}_{2}$ concentration depends on the $\mathrm{pH}$ of the medium and on the amount of $\mathrm{HCO}_{3}-$ required. Serum probably inactivates an inhibitor of capsular synthesis, and on serum or albumin agar at $\mathbf{p H ~ 6 \cdot 8 - 7 \cdot 4}$ excellent capsulation is produced by about $5 \% \mathrm{CO}_{2}$, a concentration of the order found in the mammalian body. The action of purified charcoal makes it extremely unlikely that the function of serum or albumin is to contribute an essential nutrient to the medium. The differing characteristics of growth on bicarbonate agar appear only on examining either young cultures by microscopy or fully grown overnight cultures on solid medium where the confluent growth can be compared with isolated colonies. Many investigations seem to depend solely on chemical estimations of the capsular material, poly-D-glutamic acid, made on confluent growth formed after many hours or days incubation. On bicarbonate agar, capsules only appear after the culture has become very dense, which suggests that the organisms either inactivate the inhibitor (as, for example, other species bind fatty acid or $\mathrm{Cu}^{2+}$ (Davis, 1948; von Hofsten, 1962)) or that they become resistant to its action as their growth rate falls. It is not surprising therefore that the bacteria on bicarbonate agar are grossly heterogeneous in respect of capsulation in the early phases of growth, a point clearly brought out by stained films where the majority of organisms are non-capsulated when about $1 / 10^{6}$ are fully capsulated, presumably because they come from areas of denser growth. On albumin or charcoal 
agar, the organisms are far more uniform, since capsulation begins throughout the population after 3-4 hr. incubation (see Mikhailov, Rozhkov \& Tamarin, 1960).

It is evident from Fig. 1 that a higher $\mathrm{HCO}_{3}$ - concentration is needed on bicarbonate agar, where the inhibitor is assumed to be present initially, than on albumin or charcoal agar. It may be that the inhibitor is competitively antagonized by $\mathrm{HCO}_{3}{ }^{-}$. The initial concentration of inhibitor in bicarbonate agar may, however, be so great that its effects are not overcome by any feasible $\mathrm{HCO}_{3}^{-}$concentration, but, if it is progressively inactivated by the organisms, the higher concentrations of $\mathrm{HCO}_{3}-$ used in these experiments succeed in inducing capsulation. Another explanation might be that by the time the inhibitor has become inactive, the culture has become dense and the physiology of the organisms has altered in such a way that capsular synthesis requires more $\mathrm{HCO}_{3}$ - than with a rapidly growing culture. These alternatives could be distinguished by using steady-state cultures.

The postulated inhibitor has not been identified, though a fatty acid is clearly a possibility (Table 3); nor is it known whether it occurs naturally in the culture media or is produced by the organisms themselves (see Pollock, 1949; Nieman, 1954). The latter seems less likely, for isolated organisms growing on bicarbonate agar would then be producing sufficient inhibitor to prevent their own capsulation.

The action of the inhibitor is evidently linked to the part played by $\mathrm{HCO}_{3}-$ in capsule formation. In general, $\mathrm{CO}_{2}$ assimilated by heterotrophs appears to enter the tricarboxylic acid cycle (see Wood \& Stjernholm, 1962) and, indeed, Bacillus anthracis growing on bicarbonate agar in the presence of ${ }^{14} \mathrm{CO}_{2}$ has been shown to form ${ }^{14} \mathrm{C}$-labelled aspartate, succinate, etc. (Eastin \& Thorne, 1963). Assimilation of $\mathrm{CO}_{2}$ is known to depend on the action of biotin, which is replaceable by oleic acid. If the inhibitor is indeed a fatty acid, it may therefore act by interfering specifically with this assimilatory pathway; and, judging from studies of the effects of these acids on bacterial growth (e.g. Davis \& Dubos, 1947), it would not be surprising if a given acid was stimulatory or inhibitory according to its concentration. The $\mathrm{CO}_{2}$ requirement of some species is largely removed by adding tricarboxylic acid cycle intermediates to the medium (Lwoff \& Monod, 1947; Ajl \& Werkman, 1949) but, nevertheless, capsulation did not occur in cultures of strain $2160 \mathrm{~s}$ incubated in air on either nutrient or charcoal agar containing $0.1 \mathrm{M}$-aspartate, succinate, glutamate or oxaloacetate at $\mathrm{pH} \mathrm{7 \cdot 4.} \mathrm{A} \mathrm{related} \mathrm{observation} \mathrm{was} \mathrm{that} \mathrm{glucose} \mathrm{completely}$ suppressed capsulation. At first, this was presumed to be due to the medium becoming acid and so lowering its content of $\mathrm{HCO}_{3}^{-}$(Fig. 1). However, neutral red $(\mathrm{pK}=6.85)$ did not indicate acidity, and, in any case, excellent capsules were formed even at $\mathrm{pH} 6.2$ on charcoal or albumin agar incubated in $20-40 \% \mathrm{CO}_{2}$ (Fig. 1b). Glucose may therefore specifically repress capsular synthesis in strain $2160 \mathrm{~s}$; this point is still under examination.

It is a pleasure to acknowledge the help of Dr G. M. A. Gray. 


\section{REFERENCES}

AJl, S. J. \& Werkman, C. H. (1949). Anaerobic replacement of carbon dioxide. Proc. Soc. exp. Biol. Med., N.Y. 70, 522.

Davrs, B. D. (1948). Absorption of bacteriostatic quantities of fatty acid from media by large inocula of tubercle bacilli. Pub. Hlth Rep., Wash. 63, 455.

Davis, B. D. \& Duros, R. J. (1947), The binding of fatty acids by serum albumen, a protective growth factor in bacteriological media. J. exp. Med. 86, 215.

Eastin, J. D. \& Thorne, C. B. (1963). Carbon dioxide fixation in Bacillus anthracis. J. Bact. 85, 410.

Hofsten, B. von (1962). The effect of copper on the growth of Escherichia coli. Exp. Cell Res. 26, 606.

HoLt, L. B. (1962). The culture of Bordetella pertussis. J. gen. Microbiol. 27, 323.

Housewright, R. D. (1962). The biosynthesis of homopolymeric peptides. In The Bacteria. Ed. by I. C. Gunsalus and R. Y. Stanier, vol. 3, p. 389. New York and London: Academic Press.

IvÁNovics, G. (1937). Unter welchen Bedingungen werden bei der Nährboden-Züchtung der Milzbrandbazillen Kapseln gebildet? Zbl. Bakt. (1. Abt. Orig.), 138, 449.

Knight, B. C. J. G. \& Рвоом, H. (1950). A comparative survey of the nutrition and physiology of mesophilic species in the genus Bacillus. J. gen. Microbiol. 4, 508.

Lworf, A. (1947). Sur le rôle du serum dans le développement de Moraxella lacunata et de Neisseria gonnorrhae. Ann. Inst. Pasteur, 73, 735.

LwoFf, A. \& Monon, J. (1947). Essai d'analyse du rôle de l'anhydride carbonique dans la croissance microbienne. Ann. Inst. Pasteur, 73, 323.

McCloy, E. W. (1958). Lysogenicity and immunity to Bacillus phage W. J.gen. Microbiol. $18,198$.

M'Fadyean, J. (1903). A peculiar staining reaction of the blood of animals dead of anthrax. J. comp. Path. 16, 35.

MEYNELL, E. W. (1963). Reverting and non-reverting rough variants of Bacillus anthracis. J. gen. Microbiol. 32, 55.

Meynel, G. G. (1961). Phenotypic variation and bacterial infection. Symp. Soc. gen. Microbiol. 11, 174.

Mikhailov, B. Y., Rozhkov, G. I. \& Tamarin, A. L. (1960). A rapid method for the diagnosis and detection of Bacillus anthracis. J. Microbiol., Moscow, 31, 1997.

NiEmar, C. (1954). Influence of trace amounts of fatty acids on the growth of microorganisms. Bact. Rev. 18, 147.

Nungester, W. J. (1929). Dissociation of B. anthracis. J. infect. Dis. 44, 73.

NyE, R. N. \& LAMB, M. E. (1936). Increased carbon dioxide tension as an aid in the primary isolation of certain (mephitibic) pathogenic bacteria. J. Amer. med. Ass. 106, 107.

Pollock, M. R. (1949). The effects of long-chain fatty acids on the growth of Haemophilus pertussis and other organisms. Symp. Soc. exp. Biol. 3, 193.

Renaux, E. (1952). Culture de Bacillus anthracis en milieu calcique et en milieu oxalaté. Ann. Inst. Pasteur, 83, 38.

Smith, N. R., Gordon, R. E. \& Clark, E. E. (1952). Aerobic sporeforming bacteria. U.S. Dep. Agriculture Monograph, No. 16.

STERNE, M. (1937). Variation in Bacillus anthracis. Onderstepoort J. vet. Sci. 8, 271.

Thorne, C. B. (1956). Capsule formation and glutamyl polypeptide synthesis by Bacillus anthracis and Bacillus subtilis. Symp. Soc. gen. Microbiol. 6, 68.

Thorne, C. B., Gomez, C. G. \& Housewright, R. D. (1952). Synthesis of glutamic acid and glutamyl polypeptide by Bacillus anthracis. II. The effect of carbon dioxide on peptide production on solid medium. J. Bact. 63,363 .

Umbreit, W. W., Burris, R. H. \& Stauffer, J. F. (1957). Manometric Techniques. 3rd ed. Minneapolis : Burgess Publishing Co.

Wood, H. G. \& StJernholm, R. L. (1962). Assimilation of carbon dioxide by heterotrophic organisms. In The Bacteria. Ed. by I. C. Gunsalus and R. Y. Stanier, vol. 3, p. 41 . New York and London: Academic Press. 